\title{
ANALISIS KINERJA PERUSAHAAN MENGGUNAKAN METODE BALANCE SCORECARD PADA UNIT USAHA SYARIAH PT. ASURANSI ADIRA DINAMIKA TBK
}

\author{
Eko Suryawadi ${ }^{1}$ \& Jafril Khalil ${ }^{2}$ \\ ${ }^{1 \& 2}$ Institut Teknologi dan Bisnis Ahmad Dahlan, Jakarta \\ Email:eko.suryawadi@gmail.com,jafril.khalil@gmail.com
}

\begin{abstract}
ABSTRAK
Tujuan penelitian ini adalah untuk menganilisis kinerja perusahaan dengan menggunakan metode balanced scorecard pada Unit Usaha Syariah PT. Asuransi Adira Dinamika, Tbk berdasarkan pengolahan data primer dan sekunder berupa laporan keuangan perusahaan dari tahun 2016 sampai dengan 2019 dan data primer yang berupa hasil kuesioner mengacu pada rumusan masalah dan tujuan penelitian. Desain penelitian ini kuantitatif deskriptif untuk mengetahui kinerja unit usaha syariah PT. Asuransi Adira Dinamika,Tbk, dari 4 (empat) perspektif yaitu keuangan, pelanggan, proses bisnis internal serta pembelajaran dan pertumbuhan dengan pendekatan metode balanced scorecard. Dari perspektif keuangan kinerja perusahaan secara umum sangat baik dan perusahaan dalam kategori sehat. Dari perspektif pelanggan secara umum sangat baik, tingkat kepuasan pelanggan mencapai target $88,2 \%$. Dari perspektif proses bisnis internal secara umum sangat baik, tingkat kepuasan proses bisnis di internal perusahaan mencapai target $84,8 \%$. Dan dalam perspektif pembelajaran dan pertumbuhan pencapaian target kepuasan sumber daya manusia di dalam perusahaan $87,2 \%$. Dengan hasil kinerja yang sangat baik ini memacu manajemen untuk mengembangkan unit usaha syariah menjadi perusahaan asuransi yang unggul dan kompetitif.
\end{abstract}

Kata Kunci : Asuransi Syariah, Kinerja Perusahaan, Balanced Scorecard.

\begin{abstract}
The purpose of this study is to analyze company performance using the balanced scorecard method at the Sharia Business Unit of PT. Asuransi Adira Dinamika, Tbk based on primary and secondary data management in the form of corporate financial reports from 2016 to 2019 and primary data in the form of questionnaire results referring to the formulation of the problem and research purposes. The design of this research is descriptive quantitative to determine the performance of the sharia business unit of PT Asuransi Adira Dinamika Tbk, from 4 (four) perspectives, namely finance, customers, internal business processes as well as learning and growth with the balanced scorecard method approach. From a financial perspective, the company performance is generally very good and the company is in a healthy category. From a customer perspective, it is generally very good, with the level of customer satisfaction reaching the target of $88.2 \%$. From the perspective of internal business processes, in general, it is very good, the level of satisfaction of the internal business processes of the company reaches the target of $84.8 \%$. And in the perspective of learning and growth, the achievement of human resource satisfaction targets in the company is $87.2 \%$. This excellent performance has spurred management to develop the sharia business unit into a superior and competitive insurance company.
\end{abstract}

Keywords: Sharia Insurance, Company Performance, Balanced Scorecard. 


\section{PENDAHULUAN}

Sebagai Negara mayoritas Muslim, Indonesia memiliki potensi bisnis yang besar bagi keuangan syariah. Pertumbuhan industri keuangan syariah di Indonesia mengalami kenaikan yang sangat signifikan, walaupun terbilang masih sangat kecil dan jauh dari target, dibanding dengan potensi pasar Muslim terbesar di dunia ini. Awal perkembangan asuransi syariah di Indonesia di awali dengan berdirinya PT. Syarikat Takaful Indonesia pada era 1994 yang diikuti berdirinya unit-unit layanan asuransi syariah perusahaan asuransi konvensional. Kehadiran lembaga keuangan berbasis syariah disambut antusias oleh masyarakat Muslim Indonesia terutama masyarakat Muslim yang menginginkan lembaga keuangan yang yang bebas dari maisyir, gharar dan riba' serta kesadaran ingin berhijrah dari lembaga keuangan ribawi ke lembaga keuangan berbasis syariah.

Terdapat peran penting asuransi syariah dalam menjamin keberlangsungan diri jiwa manusia dan aset yang dimiliki dari musibah dan ketidakpastian resiko yang akan terjadi. Dengan prinsip saling menolong, membantu dan melindungi antar peserta, ketidakpastian yang merupakan unsur penghambat kinerja ekonomi dapat diminimalisir dengan hadirnya produkproduk asuransi syariah. Dengan makin berkembangnya perusahaan asuransi syariah dapat beriringan dengan perkembangan pelaku ekonomi berbasis syariah dalam meminimalisir kerugian di dalam usahanya. Berikut ini data asuransi syariah yang ada di Indonesia sebagai berikut:

Tabel 1. Asuransi Syariah Indonesia Per 30 Juni 2020

\begin{tabular}{cccc}
\hline Asuransi & Full Syariah & Unit Usaha Syariah & Total \\
\hline Asuransi Jiwa & 7 & 23 & 30 \\
\hline Asuransi Umum & 5 & 24 & 29 \\
\hline Reasuransi & 1 & 2 & 3 \\
\hline TOTAL & 13 & 49 & 62 \\
\hline
\end{tabular}

Sumber : https://www.ojk.go.id, (2020)

Kinerja keuangan, kepuasan pelanggan terhadap pelayanan, proses internal yang cepat dan sumber daya manusia yang handal sebuah modal dalam meningkatkan kinerja perusahaan. Untuk mengukur dan mengevaluasi kinerja suatu perusahaan diperlukan sebuah metode yang komprehensif sehingga tujuan perusahaan akan tercapai dengan baik.

Dengan mengukur kinerja perusahaan yang memperhatikan 4 (empat) perspektif penilaian kinerja perusahaan yang menyeluruh dan berbasis keuangan dan di luar keuangan, yaitu keuangan, pelanggan, proses bisnis internal serta pembelajaran dan pertumbuhan. Balanced scorecard adalah metode yang melakukan penilaian kinerja perusahaan melalaui 4 (empat) perspektif untuk meningkatkan kepercayaan pemilik saham dan investor, meningkatkan kepuasan dan kepercayaan pelanggan akan produk dan layanan perusahaan, meningkatkan proses internal dalam operasional usaha serta kepuasan sumber daya manusia yang ada dalam perusahaan, sehingga tujuan perusahaan akan tercapai dengan baik.

Dengan latar belakang ingin mengetahui bagaimana kinerja Unit Usaha Syariah PT. Asuransi Adira Dinamika, Tbk peneliti menuangkannya dalam bentuk judul "Analisa Kinerja Perusahaan Menggunakan Metode Balanced Scorecard Pada Unit Usaha Syariah PT. Asuransi Adira Dinamika, Tbk".

\section{TINJAUAN PUSTAKA}

\section{Asuransi Syariah}

Perjanjian antara penanggung yang mengikatkan diri kepada seorang tertanggung dan jika mengalami kerugian maka dia akan menerima premi asuransi pengganti adalah pengertian dari asuransi. Asuransi Syariah dalam fatwa MUI (Dewan Syariah Nasional MUI, 2001), artinya sebagai berikut: "Fatwa No 21/DSNMUI/X/2001 Asuransi Syariah adalah : usaha saling melindungi dan tolong- 
menolong di antara sejumlah pihak melalui investasi dalam bentuk asset dan atau tabarru' yang memberikan pola pengembalian untuk menghadapi resiko tertentu melalui akad (perikatan) yang sesuai dengan syariah.

\section{Balanced Scorecard}

Balanced Scorecard adalah alat ukur kinerja perusahaan yang secara keseluruhan dalam aspek keuangan dan non keuangan dengan menggunakan 4 (empat) perspektif, yaitu keuangan, pelanggan, proses bisnis internal serta pertumbuhan dan pembelajaran (Alimudin, 2017).

Metode ini bertujuan memberi jawaban utama dalam kinerja perusahaan menurut (Hanuma, 2011) adalah:

1. Status dan kondisi perusahaan di mata pemegang saham.

2. Pandangan pelanggan terhadap perusahaan terutama pelayanannya.

3. Perusahaan yang unggul di mata mitra-mitra bisnisnya.

4. Perbaikan berkelanjutan dan penciptaaan nilai sumber daya manusia.

\section{Perspektif Keuangan}

Perspektif keuangan masih tetap digunakan dalam balance scorecard, karena indikator keuangan menunjukkan keberhasilan dalam perencanaan dan penerapan strategi perusahaan dalam meningkatkan pertumbuhan laba perusahaan. Perbaikan ini tercermin dalam sebuah tujuan secara khusus terkait dengan keuntungan yang terukur, pertumbuhan bisnis dan nilai pemegang saham.

Penelitian perspektif keuangan ini akan menggunakan pengukuran berdasarkan rasio keuangan yang digunakan asuransi kerugian sebagaimana diatur dalam Pernyataan Standar Akuntansi Keuangan (PSAK). Rumus rasio keuangan disusun dalam PSAK No. 28 Tahun 2011 Tentang perlakuan Akuntansi Asuransi Kerugian. Rasio keuangan termasuk dalam PSAK No.
28 dikutip dari (Nurfadila et al, 2015) sebagai berikut :

1. Solvency Ratio.

Solvency Margin $r$ Ratio
menggambarkan kemampuan
keuangan perusahaan dalam
memenuhi kewajiban resiko. Batas
normal rasio kecukupan solvabilitas
minimal 33,3\%.

2. Rasio Profitabilitas.

a. Underwriting Ratio, merepresentasikan tingkat underwriting yang didapat dan digunakan untuk mengukur tingkat keuntungan operasional dari kerugian operasional membandingkannya dengan pendapatan premi.

b. Rasio Beban Klaim menunjukkan klaim perusahaan. Batas normal maksimum dari rasio klaim adalah $100 \%$.

c. Rasio Komisi mempresentasikan biaya komisi yang dikeluarkan perusahaan untuk mendapatkan pendapatan.

d. Rasio Pengembalian Investasi

Rasio Pengembalian Investasi
berfungsi mengukur seberapa
banyak pencapaian investasi yang
dilakukan.

3. Rasio Likuiditas.

a. Rasio Likuiditas Aset mempresentasikan berapa besar kemampuan perusahaan dalam memenuhi kewajiban dengan bantuan aset yang yang dimiliki.

b. Investment to Technical Reserve Ratio digunakan untuk mengetahui sejauh mana kewajiban teknis yang diciptakan perusahaan asuransi tercermin dalam investasi.

4. Rasio Stabilitas Premi.

a. Rasio Pertumbuhan Premi menggambarkan besar kenaikan premi pada tahun berjalan 
dibandingkan tahun sebelumnya, apabila peningkatannya terlalu rendah tidak mencapai batas normal atau negatif dimasukkan ke dalam kelompok di luar batas normal.

b. Rasio Retensi Diri menunjukkan tingkat penjagaan perusahaan dalam menanggung resiko.

5. Rasio Teknis

Rasio kewajiban teknis menggambarkan tingkat kecukupan cadangan yang diperlukan dalam menghadapi kewajiban yang timbul dari penutupan resiko. Ada beberapa yang menyebut kewajiban teknis dengan cadangan teknis. Tidak ada batas normal untuk rasio ini, tetapi perlu diperhatikan tinggi rendahnya rasio ini apakah memberikan indikasi yang baik atau tidak. Apabila terlalu rendah dikhawatirkan cadangan teknis yang dibentuk perusahaan tidak mencukupi untuk membayar kewajibannya di masa mendatang. Sebaliknya bila terlalu tinggi menunjukkan portofolio usaha kurang merata.

Berdasarkan Peraturan Nomor 72/POJK.05/2016 tingkat kesehatan asuransi syariah dikutip dalam (Yazid, 2019), indikator yang digunakan adalah sebagai berikut:

a. Perusahaan setiap tahun wajib menetapkan target tingkat solvabilitas dengan mempertimbangkan profil risiko perusahaan minimum $120 \%$ dari DTMBR.

b. Penyisihan teknis, meliputi cadangan premi, cadangan atas premi yang belum polis atau tertanggung.

c. Ekuitas, perusahaan asuransi wajib memiliki ekuitas paling sedikit sebesar Rp. 25.000.000.000,- (seratus miliar rupiah).

d. Dana Jaminan, perusahaan wajib membentuk dana jaminan paling rendah $20 \%$ dari ekuitas minimum atau dengan $1 \%$ premi neto ditambah $0,25 \%$ premi reasuransi.

\section{Perspektif Pelanggan}

Sebagai indikator utama dalam pencapaian tujuan dan visi perusahaan, wajib memperhatikan kepuasan pelanggan dalam menganalisa komponen perspektif pelanggan. Apabila perusahaan tidak memahami kebutuhan pelanggannya maka para pesaing lebih mudah menyerang dengan menyediakan produk dan layanan yang lebih sesuai kebutuhan para pelanggan.

Kepuasan pelanggan dapat diukur dengan menggunakan kuesioner yang isi dari kuesioner tersebut mengenai dimensi kualitas pelayanan jasa seperti dalam karya ilmiah (Agusti, 2013) :

\section{a. Bukti fisik (Tangible)}

Segala hal fisik yang dapat dilihat oleh pelanggan saat melakukan layanan. Evaluasi tersebut meliputi: selalu up-to-date, fasilitas yang asri, dukungan dan kebersihan karyawan perusahaan.

b. Keandalan (Reliability).

Kemampuan perusahaan dalam memberikan jasa yang sesuai dan dapat diandalkan. Pengukurannya meliputi: komitmen terhadap janji, sikap simpatik dari perusahaan, kemampuan perusahaan dalam mengandalkan ketepatan waktu informasi dan keakuratan dari informasi lainnya.

c. Daya tangkap (Responsiveness).

Mampu memberikan pelayanan yang cepat dan efisien kepada pelanggan. Matriknya meliputi: informasi waktu, layanan yang menjanjikan, kesediaan tulus untuk membantu, dan waktu yang tersedia. Didesain sebagai daya tanggap, mau mendengarkan, menanggapi pelanggan dalam upaya memuaskan pelanggan, misalnya: kemampuan perusahaan dalam memberikan informasi secara cepat dan tepat, serta tidak menunjukkan ketidakpedulian. 
d. Kepastian (Assurance).

Mengukur kemampuan dan kesopanan karyawan serta staf dimiliki oleh perusahaan. Tindakan tersebut meliputi: kemampuan perusahaan untuk membuat pelanggan percaya dan merasa aman.

e. Empati (Empathy).

Perasaan emosional yang terbentuk saat layanan diterapkan pada pelanggan. Matriknya meliputi: sikap sopan, dukungan perusahaan, perhatian karyawan atau staf perusahaan, rasa pengertian dari perusahaan, kemampuan perusahaan memahami kebutuhan pelanggan, pelayanan professional yang membuat pelanggan merasa dispesialisasi dan panjang atau pendeknya waktu operasional dari perusahaan.

\section{Perspektif Proses Bisnis Internal}

Menurut Hery (2016), perusahaan akan mengembangkan tujuan menciptakan produk-produk baru dan berkualitas serta pelayanan di internal yang lebih baik. Perspektif proses bisnis internal ini ditetapkan setelah tujuan dan tolak ukur pada perspektif keuangan dan pelanggan terlaksana. Tahap ini akan memungkinkan bagi perusahaan untuk mencari dan mempertahankan pelanggan dalam pasar yang telah ditargetkan.

Menurut Kaplan dan Norton (1996) yang dikutip dalam Hanuma (2011), ada 3 (tiga) tahap dalam perspektif ini, yaitu :

1. Proses Inovasi.

Pengukuran ini dilakukan dengan melihat data perusahaan, inovasi apa yang dikembangkan pada tahun tersebut.

2. Proses Operasi.

Proses ini adalah fokus utama dari sebagian besar system penilaian kinerja perusahaan" dalam jurnal ilmiah.

3. Proses Pelayanan Purna jual.
Pengukuran ini dilakukan dengan melihat data perusahaan, layanan apa yang diberikan perusahaan terhadap produk atau jasa yang telah dibayar oleh pelanggan.

\section{Perspektif Pembelajaran Pertumbuhan}

dan

Sudut pandang keempat pada balanced scorecard mengedapankan ukuran dan tujuan yang bertujuan untuk mendorong pertumbuhan operasi dan organisasi. Dari perspektif pembelajaran dan pertumbuhan tujuannya adalah menyediakan infrastruktur yang mendukung tercapainya tiga perspektif sebelumnya. Terdapat dua metode pengukuran, yaitu:

1. Metode angka nilai global tunggal.

2. Metode skor penjumlahan.

\section{Penelitian Terdahulu}

Penelitian yang di lakukan oleh Styaningrum et al, (2014) yang berjudul analisis kinerja perusahaan dengan metode balanced scorecard pada Kusuma Sahid Prince Hotel Surakarta. Hasil penelitian ini menunjukkan bahwa kinerja di KSPH Surakarta pada tahun 2011-2013 berdasarkan hasil analisis terhadap empat perspektif Balances Scorecard mencapai $64.583 \%$, artinya KSPH Surakarta memiliki kualitas kinerja yang baik dalam mencapai target strategi untuk setiap perspektif di Balanced Scorecard.

Kurniasari dan Memarista (2017) meneliti tentang analisi kinerja perusahaan menggunakan balance scorecard (studi kasus PT. Aditya Sentan Agro). Hasil penelitian ini menunjukkan bahwa (1) Perspektif keuangan menunjukkan kinerja keuangan yang kurang baik karena kondisi keuangan perusahaan pada tahun 2013-2015 mengalami penurunan; (2) Dari perspektif pelanggan menunjukkan kinerja yang memuaskan karena perusahaan dapat membina dan mempertahankan hubungan baik dengan pelanggannya; (3) Perspektif bisnis internal yaitu inovasi, proses operasi dan layanan purna jual menunjukkan kinerja yang baik. (4) Perspektif pertumbuhan dan 
pembelajaran yaitu kapabilitas karyawan, kapabilitas sistem informasi serta motivasi, pemberdayaan dan keselarasan menunjukkan kinerja yang baik.

Penelitian yang dilakukan oleh Darmawan \& Suamba (2017) yang berjudul tentang analisis kinerja perusahaan CV. Bali Indah dengan metode balanced scorecard. Hasil penelitian ini menunjukkan bahwa CV. Bali Indah berdasarkan perspektif keuangan kinerjanya dinilai baik, kinerja CV. Bali Indah yang diukur dengan menggunakan indeks kepuasan pelanggan adalah sangat baik (pelanggan sangat puas), Kinerja CV. Bali Indah dari perspektif proses bisnis internal dari proses transaksi penjualan barang dinilai baik, Sedangkan kinerja CV. Bali Indah yang diukur dengan menggunakan indeks kepuasan karyawan adalah baik (karyawan puas). Jadi dari perspektif pembelajaran dan pertumbuhan CV. Bali Indah dinilai baik.

Penelitian yang dilakukan oleh Putra (2014) yang berjudul tentang analisis kinerja perusahaan dengan metode balance scorecard (studi kasus pada PT. Putra Tidar Perkasa). Hasil penelitian ini menemukan bahwa kinerja perusahaan dengan perspektif keuangan yang baik karena dapat meningkat secara signifikan pada tahun 2012 meskipun kehilangan perspektif yang hebat. dan untuk kepuasan pelanggan umum untuk layanan yang disediakan oleh PTP dan meningkatkan pelanggan baru setiap tahunnya. Perspektif Belajar dan Pertumbuhan dikatakan baik sebagai karyawan di PTP Memiliki defisit yang tinggi meningkatkan produktivitas. Dari empat perspektif tersebut PT. Putra Tidar.
Perkasa menilai kinerjanya cukup baik.

\section{METODE PENELITIAN}

Metode yang digunakan dalam penelitian ini adalah metode penelitian kuantitatif deskriptif. Metode deskriptif pendekatan kuantitatif dengan analisis balanced scorecard meliputi langkahlangkah sebagai berikut:

1. Menghitung kinerja perusahaan dari perspektif keuangan yang berkaitan dengan laporan keuangan perusahaan periode tahun 2016 - 2019 yang telah di audit dan dipubikasikan.

2. Menghitung kinerja perusahaan dari perspektif pelanggan dengan mengukur tingkat kepuasan pelanggan yaitu, pengolahan data primer yang diperoleh dari pengisian kuesioner oleh para responden diubah menjadi data kuantitatif dengan memberikan skor masing-masing pilihan jawaban dengan skala likert (Sugiyono, 2017).

3. Menghitung kinerja perusahaan dari perspektif proses bisnis internal diukur melalui indikator inovasi produk, pelayanan polis dan proses klaim dengan pengolahan data primer hasil kuisioner oleh para responden.

4. Menghitung kinerja perusahaan dari perspektif pembelajaran dan pertumbuhan dengan pengolahan data primer hasil kuesioner para responden yang diisi oleh karyawan atau sumber daya manusia.

HASIL DAN PEMBAHASAN

Uji Validitas dan Uji Reliabilitas.

Tabel 2. Rekapitulasi Uji Validitas dan Reliabilitas Kepuasan Pelanggan

\begin{tabular}{|c|c|c|c|c|c|c|c|}
\hline Indikator & $\begin{array}{c}\mathbf{R} \\
\text { hitung }\end{array}$ & Sig & $\underset{\text { tabel }}{\mathbf{r}}$ & Kesimpulan & $\begin{array}{c}\text { Cronbach's } \\
\text { Alpha }\end{array}$ & $\begin{array}{c}\text { Titik } \\
\text { kritis }\end{array}$ & Kesimpulan \\
\hline plg1 & 0.685 & 0.000 & 0.220 & Valid & \multirow{6}{*}{0.854} & \multirow{6}{*}{0.7} & \multirow{6}{*}{ Reliabel } \\
\hline plg2 & 0.397 & 0.000 & 0.220 & Valid & & & \\
\hline plg3 & 0.735 & 0.000 & 0.220 & Valid & & & \\
\hline plg4 & 0.671 & 0.000 & 0.220 & Valid & & & \\
\hline plg5 & 0.538 & 0.000 & 0.220 & Valid & & & \\
\hline plg6 & 0.526 & 0.000 & 0.220 & Valid & & & \\
\hline
\end{tabular}




\begin{tabular}{ccccc}
\hline plg7 & 0.532 & 0.000 & 0.220 & Valid \\
\hline$p \lg 8$ & 0.617 & 0.000 & 0.220 & Valid \\
\hline$p \lg 9$ & 0.430 & 0.000 & 0.220 & Valid \\
\hline$p \lg 10$ & 0.450 & 0.000 & 0.220 & Valid \\
\hline$p \lg 11$ & 0.622 & 0.000 & 0.220 & Valid \\
\hline$p \lg 12$ & 0.439 & 0.000 & 0.220 & Valid \\
\hline$p \lg 13$ & 0.589 & 0.000 & 0.220 & Valid \\
\hline$p \lg 14$ & 0.765 & 0.000 & 0.220 & Valid \\
\hline plg15 & 0.623 & 0.000 & 0.220 & Valid
\end{tabular}

\section{Sumber : Data Olahan (2021)}

Pada tabel 2 di atas diketahui bahwa jumlah sampel 80, nilai $r$ tabel adalah 0,220. Berdasarkan tabel di atas, nilai $r$ hitung tertinggi adalah 0,765 (indikator $\mathrm{kp} 14$ ) sedangkan nilai $\mathrm{r}$ hitung terendah adalah 0,397 (indikator kp2). Karena semua indikator memiliki nilai $r$ hitung yang lebih besar dari $r$ tabel $(0,220)$ maka disimpulkan bahwa semua indikator tersebut adalah valid.

Nilai Cronbach alpha yang diperoleh adalah 0,854 , karena nilainya lebih dari 0,7 maka disimpulkan bahwa variabel tersebut adalah reliabel.

Tabel 3. Rekapitulasi Uji Validitas dan Reliabilitas Proses Bisnis Internal

\begin{tabular}{|c|c|c|c|c|c|c|c|}
\hline Indikator & $\begin{array}{c}\mathbf{r} \\
\text { hitung }\end{array}$ & Sig & $\begin{array}{c}r \\
\text { tabel }\end{array}$ & Kesimpulan & $\begin{array}{c}\text { Cronbach's } \\
\text { Alpha }\end{array}$ & $\begin{array}{r}\text { Titik } \\
\text { kritis }\end{array}$ & Kesimpulan \\
\hline pbil & 0.544 & 0.005 & 0.396 & Valid & \multirow{10}{*}{0.841} & \multirow{10}{*}{0.7} & \multirow{10}{*}{ Reliabel } \\
\hline pbi2 & 0.453 & 0.023 & 0.396 & Valid & & & \\
\hline pbi3 & 0.595 & 0.002 & 0.396 & Valid & & & \\
\hline pbi4 & 0.516 & 0.008 & 0.396 & Valid & & & \\
\hline pbi5 & 0.468 & 0.018 & 0.396 & Valid & & & \\
\hline pbi6 & 0.819 & 0.000 & 0.396 & Valid & & & \\
\hline pbi7 & 0.766 & 0.000 & 0.396 & Valid & & & \\
\hline pbi8 & 0.689 & 0.000 & 0.396 & Valid & & & \\
\hline pbi9 & 0.721 & 0.000 & 0.396 & Valid & & & \\
\hline pbi10 & 0.785 & 0.000 & 0.396 & Valid & & & \\
\hline
\end{tabular}
Sumber : Data Olahan (2021)

Pada tabel 3 di atas jumlah sampel 25 , nilai $\mathrm{r}$ tabel adalah 0,396 . Berdasarkan tabel di atas, nilai $r$ hitung tertinggi adalah 0,819 (indikator pbi6) sedangkan nilai $\mathrm{r}$ hitung terendah adalah 0,453 (indikator pbi2). Karena semua indikator memiliki nilai $r$ hitung yang lebih besar dari $r$ tabel $(0,396)$ maka disimpulkan bahwa semua indikator tersebut adalah valid. Nilai cronbach alpha yang diperoleh adalah 0,841 , karena nilanya lebih dari 0,7 maka disimpulkan bahwa variabel tersebut adalah reliabel.

Tabel 4. Rekapitulasi Uji Validitas dan Reliabilitas Pembelajaran Dan Pertumbuhan

\begin{tabular}{|c|c|c|c|c|c|c|c|}
\hline Indikator & $\begin{array}{c}\mathbf{R} \\
\text { hitung }\end{array}$ & Sig & $\begin{array}{c}R \\
\text { tabel }\end{array}$ & Kesimpulan & $\begin{array}{c}\text { Cronbach's } \\
\text { Alpha }\end{array}$ & Titik kritis & Kesimpulan \\
\hline pp1 & 0.599 & 0.001 & 0.381 & Valid & \multirow{10}{*}{0.808} & \multirow{10}{*}{0.7} & \multirow{10}{*}{ Reliabel } \\
\hline $\mathrm{pp} 2$ & 0.573 & 0.002 & 0.381 & Valid & & & \\
\hline $\mathrm{pp} 3$ & 0.550 & 0.003 & 0.381 & Valid & & & \\
\hline pp4 & 0.561 & 0.002 & 0.381 & Valid & & & \\
\hline pp5 & 0.543 & 0.003 & 0.381 & Valid & & & \\
\hline pp6 & 0.744 & 0.000 & 0.381 & Valid & & & \\
\hline pp7 & 0.595 & 0.001 & 0.381 & Valid & & & \\
\hline $\mathrm{pp} 8$ & 0.633 & 0.000 & 0.381 & Valid & & & \\
\hline pp9 & 0.638 & 0.000 & 0.381 & Valid & & & \\
\hline pp10 & 0.650 & 0.000 & 0.381 & Valid & & & \\
\hline
\end{tabular}


Sumber : Data Olahan (2021)

Pada tabel 5 jumlah sampel 27, nilai r tabel adalah 0,381. Berdasarkan tabel di atas, nilai $r$ hitung tertinggi adalah 0,744 (indikator sdm6) sedangkan nilai $r$ hitung terendah adalah 0,543 (indikator sdm5). Karena semua indikator memiliki nilai $r$ hitung yang lebih besar dari $r$ tabel $(0,381)$ maka disimpulkan bahwa semua indikator tersebut adalah valid. Nilai cronbach alpha yang diperoleh adalah 0,808 , karena nilanya lebih dari 0,7 maka disimpulkan bahwa variabel tersebut adalah reliabel.

Hasil Analisa Kinerja Perusahaan Unit Usaha Syariah PT. Asuransi Adira Dinamika,Tbk menggunakan Metode Balance Scorecard.

1. Laporan Kinerja Perusahaan Unit Usaha Syariah dalam Perspektif Keuangan.

Tabel 5. Kinerja Keuangan Unit Usaha Syariah

\begin{tabular}{ccccc}
\hline No & Rasio & Batas Normal & $\begin{array}{c}\text { Realisasi } \\
\text { Rata-rata }\end{array}$ & Penilaian \\
\hline 1 & Solvency Margin Ratio & Minimal 33,3\% & $214 \%$ & Baik \\
\hline 2 & Underwriting Ratio & Minimal 40\% & $18 \%$ & Tidak Baik \\
\hline 3 & Rasio Beban Klaim & Maksimal 100\% & $38 \%$ & Baik \\
\hline 4 & Rasio Komisi & - & $45 \%$ & Baik \\
\hline 5 & Rasio Pengembalian investasi & Minimal 15\% & $2 \%$ & Tidak Baik \\
\hline 6 & Rasio Likuiditas Aset & Maksimal 120\% & $50 \%$ & Baik \\
\hline 7 & Investment to Technical Reserve Ratio & - & $282 \%$ & Baik \\
\hline 8 & Rasio Pertumbuhan Premi & Minimal 23\% & $16 \%$ & Tidak Baik \\
\hline 9 & Rasio Retensi Diri & - & $102 \%$ & Baik \\
\hline 10 & Rasio Kewajiban Teknis & - & $2316 \%$ & Baik \\
\hline 11 & Risk Based Capital & Minimal 120\% & & Baik \\
\hline
\end{tabular}

Sumber: Data Olahan (2021)

Tabel 6. Tingkat Kesehatan Unit Usaha Syariah PT. Asuransi Adira Dinamika,Tbk

\begin{tabular}{|c|c|c|c|c|}
\hline \multirow{3}{*}{ Indikator } & \multirow{3}{*}{$\begin{array}{c}\text { Standar P. } 72 \\
\text { POJK.05/ } \\
2016\end{array}$} & \multirow{2}{*}{\multicolumn{2}{|c|}{ Rata-rata }} & \multirow{3}{*}{ Penilaian } \\
\hline & & & & \\
\hline & & Tabarru & Persh & \\
\hline Tingkat Solvabilitas & $>120 \%$ & $963 \%$ & $4360 \%$ & Sesuai target di POJK \\
\hline Cadangan Teknis & & \multicolumn{2}{|c|}{$312,666,000,000$} & Sesuai target di POJK \\
\hline Kecukupan Investasi & & \multicolumn{2}{|c|}{$314,214,000,000$} & Sesuai target di POJK \\
\hline Ekuitas & $>25,000,000,000$ & \multicolumn{2}{|c|}{$337,247,000,000$} & Sesuai target di POJK \\
\hline Dana Jaminan & & \multicolumn{2}{|c|}{$5,614,847,500$} & Sesuai target di POJK \\
\hline
\end{tabular}

Sumber : Data Olahan (2021) 
Dari tabel 6 di samping diketahui bahwa, rasio-rasio keuangan solvency margin ratio jauh di atas batas minimal $33,3 \%$ yaitu $214 \%$ ini menggambarkan perusahaan sangat sehat, rasio beban klaim di bawah batas maksimal $100 \%$ yaitu $38 \%$ artinya pendapatan kontribusi bisa membiayai klaim yang terjadi. Rasio Likuiditas aset di bawah batas maksimal $120 \%$ yaitu $50 \%$ artinya bahwa asetnya bisa membayar kewajiban $50 \%$ dari aset, perusahaan sangat sehat. Rasio pertumbuhan premi di bawah batas normal $23 \%$ yaitu $16 \%$ artinya penurunan pendapatkan kontribusi selama tahun 2018 dan 2019 karena kondisi ekonomi pada saat itu. Rasio komisi dan rasio kewajiban teknis tidak ada batas normal tapi perusahaan wajib mengontrol sesuai dengan aturan-aturan Otoritas Jasa Keuangan, Risk Based Capital juga rata-rata $2316 \%$ kondisi perusahaan sangat sehat apabila terjadi klaim besar, perusahaan sanggup membayar kewajibannya. Dari tabel 6 bahwa dalam kategori sehat dengan tingkat solvabilitas Tabarru $963 \%$ dan tingkat solvabilitas Dana Perusahaan $4360 \%$.

2. Laporan Kinerja Perusahaan Unit Usaha Syariah dalam Perspektif Kepuasan Pelanggan.

Tabel 7. Skor Kepuasan Pelanggan

\begin{tabular}{cc}
\hline PERNYATAAN & SKOR \\
\hline Bukti Fisik (Tangible) & 4.35 \\
\hline Keandalan (Reliability) & 4.46 \\
\hline Daya Tanggap (Responsiveness) & 4.35 \\
\hline Kepastian (Assurance) & 4.39 \\
\hline Empati (Emphaty) & 4.49 \\
\hline Total Rata-Rata Skor & $\mathbf{4 . 4 1}$ \\
\hline
\end{tabular}

Sumber : Data Olahan (2021)

Dengan rata-rata skor pada tabel 9 dari kuesioner kepuasan pelanggan yang dibagikan ke pelanggan atau peserta asuransi Unit Usaha Syariah PT. Asuransi Adira Dinamika, Tbk dapat disimpulkan tingkat kepuasan pelanggan sebagai berikut:

Dengan target dengan skor 5 untuk kepuasan pelanggan, perusahaan berharap semua pelanggan sangat puas dengan semua aspek yang berkaitan dengan kepuasan pelanggan, kepuasan pelanggan mendapatkan skor 4.41. Oleh karena itu, pencapaian target dari kepuasan pelanggan dihasilkan dengan perhitungan sebagai berikut:

Tinggat Kepuasan SDM $=\frac{4.41}{5} \times 100 \%$ $=88,2 \%$ (Kategori Sangat Puas).

Dengan tingkat kepuasan $88.2 \%$ maka pelanggan Unit Usaha Syariah sangat puas dengan pelayanan yang diberikan perusahaan.

3. Laporan Kinerja Perusahaan Unit Usaha Syariah dalam Perspektif Proses Bisnis Internal

Tabel 8. Skor Kepuasan Proses Bisnis Internal

\begin{tabular}{cc}
\hline PERNYATAAN & SKOR \\
\hline Proses Inovasi & 4.39 \\
\hline Proses Operasi & 4.09 \\
\hline Proses Pelayanan Purna Jual & 4.24 \\
\hline Total Rata-Rata Skor & 4.24 \\
\hline
\end{tabular}

Sumber : Data Olahan (2021)

Dengan rata-rata skor pada tabel 10 dari kuesioner proses bisnis internal yang dibagikan ke mitra bisnis Unit Usaha Syariah PT. Asuransi Adira Dinamika,Tbk dapat disimpulkan tingkat kepuasan proses bisnis internal sebagai berikut: 
Dengan target dengan skor 5 untuk kepuasan proses bisnis internal, perusahaan mengharapkan semua mitra bisnis merasa puas dengan keseluruhan aspek yang terkait dengan kepuasan proses bisnis internal. Realisasi dari kepuasan proses bisnis internal tercapai skor 4.24.

Oleh karena itu, pencapaian target dari kepuasan proses bisnis internal dihasilkan dengan perhitungan sebagai berikut:

$$
\begin{gathered}
\text { Tinggat Kepuasan PIB }=\frac{4.24}{5} \times 100 \% \\
=84,8 \% \text { (Kategori Sangat Puas). }
\end{gathered}
$$

Dengan pencapaian target $84.8 \%$ ini Unit Usaha Syariah bisa menjadikan dasar bahwa kepuasan mitra bisnis dengan proses pelayanan polis dan produk unggulan yang dimiliki Unit Usaha Syariah sangat puas.
Mitra bisnis sebagai agen penjual produk-produk asuransi membutuhkan produk-produk yang unggul di pasar, layanan polis yang cepat dan proses klaim yang mudah. Proses bisnis internal yang terdapat di Unit Usaha Syariah adalah sebagai berikut :

Produknya inovatif selalu mengikuti tren pasar, terutama di era digitalisasi sekarang, mitra bisnis bisa order lewat aplikasi. Proses penerbitan polis yang lebih simple dan cepat, sehingga pelanggan merasa cepat terlindungi asetnya pelayanan purna jual dengan proses klaim yang mudah dan cepat.

\section{Laporan Kinerja Perusahaan Unit Usaha Syariah dalam Perspektif Pembelajaran dan Pertumbuhan.}

Tabel 9. Skor Kepuasan Sumber Daya Manusia

\begin{tabular}{cc}
\hline PERNYATAAN & SKOR \\
\hline Apresiasi & 4.39 \\
\hline Motivasi & 4.32 \\
\hline Total Rata-Rata Skor & $\mathbf{4 . 3 6}$ \\
\hline
\end{tabular}

Sumber : Data Olahan (2021)

Dengan rata-rata skor pada tabel 13 dari kuesioner kepuasan sumber daya manusia yang dibagikan ke sumber daya manusia Unit Usaha Syariah PT. Asuransi Adira Dinamika,Tbk dapat disimpulkan tingkat kepuasan sumber daya manusia sebagai berikut :

Dengan target dengan skor 5 untuk kepuasan sumber daya manusia, perusahaan mengharapkan semua sumber daya manusia merasa puas dengan keseluruhan aspek yang terkait dengan kepuasan sumber daya manusia baik dari sisi apresiasi ataupun motivasi. Realisasi dari kepuasan sumber daya manusia tercapai skor 4.24.

Oleh karena itu, pencapaian target dari kepuasan sumber daya manusia dihasilkan dengan perhitungan sebagai berikut:

$$
\text { Tinggat Kepuasan SDM }=\frac{4.36}{5} \times 100 \%
$$

$=87,2 \%$ (Kategori Sangat Puas)

Dengan pencapaian target sumber daya manusia $87.2 \%$ memacu semangat manajemen untuk memberikan yang terbaik buat sumber daya manusianya.

\section{KESIMPULAN}

Pengukuran kinerja perusahaan Unit Usaha Syariah PT. Asuransi Adira Syariah,Tbk dapat terukur dengan melihat dari 4 (empat) perspektif dalam teori scorecard balance yaitu, dalam perspektif keuangan perusahaan dengan tingkat solvabilitas dan Risk Based Capital yang jauh di atas dari ketentuan regulator yaitu minimal $120 \%$ menjadikan Unit Usaha Syariah PT Asuransi Adira Dinamika,Tbk perusahaan asuransi yang baik dan sehat.

Dalam perspektif pelanggan dilihat dari jawaban para responden yang sangat 
puas dengan pelayanan Unit Usaha Syariah dengan interprestasi yang baik, pelanggan sangat puas dengan pelayanan yang dilakukan oleh semua elemen perusahaan.

Dalam perspektif proses bisnis internal dilihat dari jawaban para responden yang merupakan mitra bisnis pemasaran produk-produk asuransi syariah. Proses penutupan asuransi yang mudah dan proses polis yang cepat menjadi catatan tersendiri bagi mitra bisnis untuk loyal ke perusahaan dalam melayani peserta asuransi.

Dan terakhir dilihat perspektif pembelajaran dan pertumbuhan dari jawaban responden yang merupakan sumber daya manusia yang bekerja di Unit Usaha Syariah PT Asuransi Adira Dinamika,Tbk. Loyalitas sumber daya manusia yang ada dalam perusahaan harus menjadi modal dalam pencapaian target perusahaan.

Sehingga dari 4 (empat) perspektif ini, dapat disimpulkan bahwa kinerja perusahaan unit usaha syariah PT. Asuransi Adira Dinamika sangat baik sehingga memacu manajemen untuk mengembangkan unit usaha syariah ini menjadi perusahaan asuransi syariah yang unggul dan kompetitif.

\section{DAFTAR PUSTAKA}

Agusti, Netta. 2018. The Balanced Scorecard: Maksimalisasi Empat Perspektif Strategis Asuransi Syariah. JEBI (Jurnal Ekonomi dan Bisnis Islam), 3(1), p. 120-134.

Alimudin, A. 2017. Analisis Pencapaian Strategi Menggunakan Balanced Scorecard. Jurnal Pendidikan Ekonomi Dan Bisnis (JPEB), 5(2), 194-205.

Darmawan, P.S. Saraswati, D.P., \& Suamba, K. 2017. Analisis Kinerja Perusahaan CV. Bali Indah dengan Metode Balanced Scorecard. Jurnal Manajamen Agribisnis, 5(1), p. 45-63.

Dewan Syariah Nasional MUI. 2001. Fatwa DSN-MUI No.21/DSN-MUI/X/2001 tentang Pedoman Umum Asuransi Syariah.

Hanuma, S. 2011. Analisis Balance Scorecard Sebagai Alat Pengukur Kkinerja Perusahaan (Studi Kasus pada PT. Astra Honda Motor). Skripsi Fakultas Ekonomi Universitas Diponegoro.

Hery. 2016. Balanced Scorecard For Business. Grasindo. Jakarta.

Kuniasari, Verni., \& Memarista, Gesti. 2017. Analisis Kinerja Perusahaan menggunakan Balanced Scorecard (Studi Kasus Pada PT. Adiya Sentana Agro). AGORA, 5(1).

Nurfadila, S., Hidayat, R. R., \& Sulasmiyati, S. 2015. Analisis Rasio Keuangan dan Risk Based Capital untuk Menilai Kinerja Keuangan Perusahaan Asuransi. Jurnal Administrasi Bisnis. Universitas Brawijaya. 22(1).

Putra, Rizki Eka. 2014. Analisis Kinerja Perusahaan dengan Metode Balance Scorecard (studi kasus pada PT. Putra Tidar Perkasa). Jurnal Measurement, 8(1), p. 37-50.

Styaningrum, Farida., Sulistyadi, Kohar., Riani, Asri Laksmi. 2014. Analisis Kinerja Perusahaan dengan Metode Balanced Scorecard pada Kusuma Sahid Prince Hotel Surakarta. Jurnal Pendidikan Insan Mandiri, 3(1), p. 3243.

Sugiyono. 2017. Metode Penelitian Pendidikan (Pendekatan Kuantitatif, Kualitatif dan R\&D). CV Alfabeta. Bandung.

Yazid, B, Ahmad. 2019. Analisis Balance Scorecard dalam menilai kerja PT. Asuransi Ramayana Unit Syariah untuk melakukan spin off paling lambat tahun 2024. Tesis Sekolah Tinggi Ilmu Ekonomi Indonesia. 